\title{
Encounters by the Rivers of Babylon
}

\section{Scholarly Conversations Between Jews, Iranians and Babylonians in Antiquity Ed. by Uri Gabbay and Shai Secunda}

[Begegnungen an den Strömen Babylons. Akademische Gespräche zwischen Juden, Iranern und Babyloniern in der Antike.]

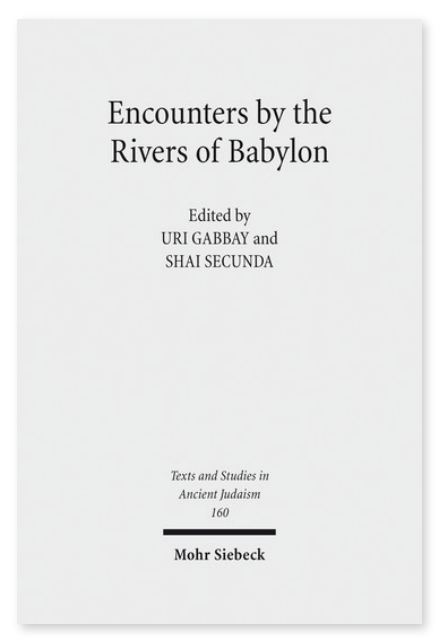

2014. VI, 469 Seiten. TSAJ 160

ISBN 978-3-16-153037-1

DOI 10.1628/978-3-16-153037-1

eBook PDF $219,00 €$

ISBN 978-3-16-152833-0

Leinen $219,00 €$
Veröffentlicht auf Englisch.

Dieser Band versammelt Beiträge, die sich mit den Beziehungen zwischen antiken babylonischen, iranischen und jüdischen Gemeinden in Mesopotamien unter neubabylonischer, achämenidischer und sassanidischer Herrschaft befassen. In den Aufsätzen untersuchen führende Wissenschaftler aus den Fachgebieten der Assyriologie, der Iranistik und der Judaistik verschiedene Modi der kulturellen Beziehungen zwischen diesen Gesellschaften, zum Beispiel historische, sozial, legale und exegetische Schnittpunkte. Die zahlreichen mesopotamischen Beziehungen, die in Untersuchungen des antiken Judentums allzu oft vernachlässigt werden, stehen im Mittelpunkt dieser interdisziplinären Sammlung.

Inhaltsübersicht

Uri Gabbay/Shai Secunda: Introduction

Yaakov Elman: Contrasting Intellectual Trajectories: Iran and Israel in Mesopotamia

Society and Its Institutions Ran Zadok: Judeans in Babylonia-Updating the Dossier - Caroline Waerzeggers: Locating Contact in the Babylonian Exile: Some Reflections on Tracing Judean-Babylonian Encounters in Cuneiform Texts - Maria Macuch: Jewish Jurisdiction within the Framework of the Sasanian Legal System

The Transmission of Knowledge Abraham Winitzer: Assyriology and Jewish Studies in Tel Aviv: Ezekiel among the Babylonian literati - Jonathan Ben-Dov: Time and Culture: Mesopotamian Calendars in Jewish Sources from the Bible to the Mishnah Nathan Wasserman: Old-Babylonian, Middle-Babylonian, Neo-Babylonian, Jewish-Babylonian? Thoughts about Transmission Modes of Mesopotamian Magic through the Ages - James Nathan Ford: The Ancient Mesopotamian Motif of kidinnu 'divine protection (of temple cities and their citizens)' in Akkadian and Aramaic Magic - Reuven Kiperwasser/Dan D. Y. Shapira: Encounters between Iranian Myth and Rabbinic Mythmakers in the Babylonian Talmud

Scholasticism and Exegesis Irving Finkel: Remarks on Cuneiform Scholarship and the Babylonian Talmud - Eckart Frahm: Traditionalism and Intellectual Innovation in a Cosmopolitan World: Reflections on Babylonian Text Commentaries from the Achaemenid Period - Uri Gabbay: Actual Sense and Scriptural Intention: Literal Meaning and Its Terminology in Akkadian and Hebrew Commentaries - Prods Oktor Skjærvø: Abar Rōdestān ī Babēl: The Zoroastrian Tradition一the dēn-in Sasanian and Early Islamic Times - Shai Secunda: Rabbinic and Zoroastrian Hermeneutics: Background and Prospects - Yishai Kiel: Shaking Impurity: Scriptural Exegesis and Legal Innovation in the Babylonian Talmud and Pahlavi Literature

Uri Gabbay Born 1975; PhD in Assyriology at Hebrew University; Senior Lecturer in Hebrew University Jerusalem.

Shai Secunda Born 1979; PhD in Talmud from Yeshiva University; Fellow at the Martin Buber Society of Fellows, Hebrew University of Jerusalem.

Jetzt bestellen:

https://mohrsiebeck.com/buch/encounters-by-the-rivers-of-babylon-9783161530371?no_cache=1

order@mohrsiebeck.com

Telefon: +49 (0)7071-923-17

Telefax: $+49(0) 7071-51104$ 